\title{
Excavation of a Portion of the San Pedro Acequia (41BX337) via Metropolitan Transit System Parking Lot, San Antonio, Bexar County, Texas
}

\author{
I. Waynne Cox \\ Center for Archaeological Research
}

Follow this and additional works at: https://scholarworks.sfasu.edu/ita

Part of the American Material Culture Commons, Archaeological Anthropology Commons, Environmental Studies Commons, Other American Studies Commons, Other Arts and Humanities Commons, Other History of Art, Architecture, and Archaeology Commons, and the United States History Commons

Tell us how this article helped you.

This Article is brought to you for free and open access by the Center for Regional Heritage Research at SFA ScholarWorks. It has been accepted for inclusion in Index of Texas Archaeology: Open Access Gray Literature from the Lone Star State by an authorized editor of SFA ScholarWorks. For more information, please contact cdsscholarworks@sfasu.edu. 


\section{Excavation of a Portion of the San Pedro Acequia (41BX337) via Metropolitan Transit System Parking Lot, San Antonio, Bexar County, Texas}

\section{Creative Commons License}

\section{(c) (1) \&}

This work is licensed under a Creative Commons Attribution-NonCommercial 4.0 International License 
EXCAVATION OF A PORTION OF THE SAN PEDRO ACEQUIA (41 BX 337) VIA METROPOLITAN TRANSIT SYSTEM PARKING LOT, SAN ANTONIO, BEXAR COUNTY, TEXAS

I. Waynne Cox

Center For Archaeological Research The University of Texas at San Antonio Archaeological Survey Report, No. 219 
EXCAVATION OF A PORTION OF THE SAN PEDRO ACEQUIA (41 BX 337) VIA METROPOLITAN TRANSIT SYSTEM PARKING LOT, SAN ANTONIO, BEXAR COUNTY, TEXAS

I. Waynne Cox

Texas Antiquities Permit No. 587

Center For Archaeological Research The University of Texas at San Antonio ${ }^{(1)}$ Archaeological Survey Report, No. 219 
The following information is provided in accordance with General Rules of Practice and Procedure Chapter 41.11 (Investigation Reports), Texas Antiquities Committee:

1. Type of investigation: Archaeological testing on the San Pedro Acequia, San Antonio, Texas.

2. Project name: VIA Pavement Rehabilitation Project.

3. County: Bexar County, Texas.

4. Principal investigators: Thomas R. Hester and Jack D. Eaton.

5. Name and location of sponsoring agency: VIA Metropolitan Transit System, 800 West Myrtle, San Antonio, Texas 78212.

6. Texas Antiquities Committee Permit No. 587.

7. Published by the Center for Archaeological Research, The University of Texas at San Antonio, Texas 78249-0658, 1993.

A list of publications by the Center for Archaeological Research can be obtained by sending $\$ 1.00$ to the Center for Archaeological Research, The University of Texas at San Antonio, San Antonio, Texas 78249-0658. 


\begin{abstract}
In October of 1986, representatives of the VIA Metropolitan Transit System contacted the Center for Archaeological Research prior to construction on their bus parking lot that occupies the area above a section of the historic San Pedro Acequia. It was decided at that time that limited testing to define and locate the extent of the acequia remaining and determine if monitoring of further operations should be conducted. The excavations were accomplished in December of 1986 and a profile of the acequia recorded. At that time monitoring was delayed until the anticipated relocation of a fuel storage tank was to be accomplished; subsequent problem with the location of the tank because of environmental considerations delayed the project for a period of time, eventually requiring placement of the storage tank well away from the path of the acequia.
\end{abstract}




\section{TABLE OF CONTENTS}

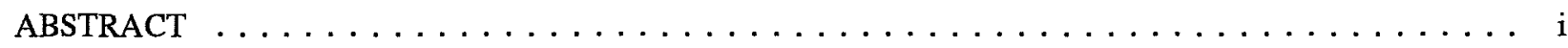

LIST OF FIGURES $\ldots \ldots \ldots \ldots \ldots \ldots \ldots \ldots \ldots \ldots \ldots \ldots \ldots \ldots \ldots \ldots \ldots \ldots$ ii

ACKNOWLEDGMENTS $\ldots \ldots \ldots \ldots \ldots \ldots \ldots \ldots \ldots \ldots \ldots \ldots \ldots \ldots \ldots \ldots$ iii

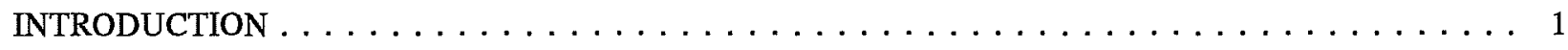

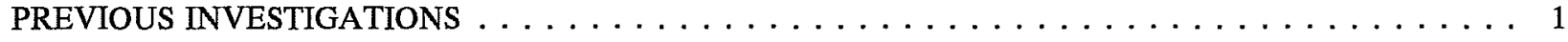

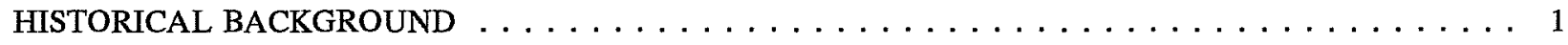

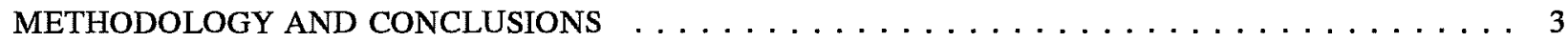

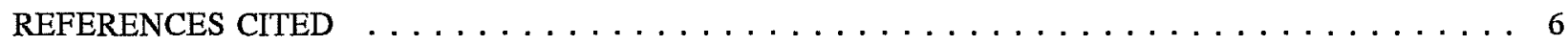

\section{LIST OF FIGURES}

1. Locations of Excavated Trenches and San Pedro Acequia $\ldots \ldots \ldots \ldots \ldots \ldots \ldots$

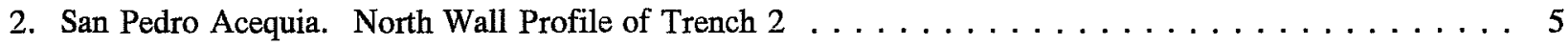




\section{ACKNOWLEDGMENTS}

We would like to take this opportunity to thank the staff of VIA Metropolitan Transit Company for their cooperation in opening their map collection and files for research during the production of this report. Their assistance and provision of excavation equipment during the field work was invaluable. Also, John Ogden Leal, Bexar County archivist, for information from the county records concerning the growth of the area. 


\section{INTRODUCTION}

On October 15, 1986, representatives of the Center for Archaeological Research, The University of Texas at San Antonio (CAR-UTSA), met with Rod Smith, Manager of Capital Developments, for the VIA Metropolitan Transit System (VIA) and other staff members in regard to their proposed alterations to the bus parking facilities between West Myrtle and Evergreen Streets. They were well aware of the existence of the buried historic San Pedro Acequia within the area and were seeking advice on how this unique resource should be protected. It was recommended by the CAR that limited mechanical excavations be conducted to determine the location, depth, size and condition of the acequia and document this for future reference. On December 2nd and 3rd, 1986, investigations were conducted with a 510B backhoe, supplied by VIA, and operated by the F\&E Construction Company. The principal investigators were Thomas R. Hester, Director, and Jack D. Eaton, Associate Director of the CAR. The field crew consisted of Waynne Cox, Research Associate, and Cathy Dodt and Kelly Scott, Technical Staff Assistants.

\section{PREVIOUS INVESTIGATIONS}

Previous archaeological investigations of the San Pedro Acequia have been conducted on stone lined sections of the channel located within the area of the Bexar County Justice Center and on the grounds of the Arsenal (Fox 1978; Fox et al. 1989). Extensive investigations of the acequia conducted between West Sheridan and West Guenther Streets produced profiles of both lined and unlined sections of the channel (Frkuska 1981). Previous excavations in the VIA parking lot, between Evergreen and Laurel, just to the south of the present study area also produced both lined and unlined section of the ditch (Cox 1986).

\section{HISTORICAL BACKGROUND}

The system of acequias introduced by the Spanish to the New World was an essential quality that allowed the exploitation of vast areas of semiarid lands throughout the frontier of New Spain. San Antonio proved to be an ideal location for their development; fed by the springs of the Edwards Aquifer, they served the entire valley for all the settlers until into the beginning of the 20th century. Of the several acequias constructed by the Spanish, the San Pedro was one of the longest lived and most successful.

On March 9, 1731, 56 Canary Islanders arrived at the presidio to form the nucleus of the Villa of San Fernando de Bexar, the first civil settlement of Texas. Viceroy Casafuente had ordered that the newcomers be greeted and housed in the presidio until the villa was established a "...gunshot's distance...to the west of the presidio" (A. de Aviles, 1732, "Carpeta de Correspondencia de la Provincicas Internas por los años de 1726 a 1731." Archivo General Nacional de Mexíco, Richard Garay Collection, San Antonio, Volume 236:28). The captain of the Presidio, Juan Antonio Pérez de Alamazán, delayed the laying out of the villa until after the planting season, selecting "land subject to irrigation" as temporary fields for the Islanders (J. A. P. de Alamazán, 1731, "Report of the Survey of the Original Town Tract of San Fernando de Bexar." Barker History Center, Austin, Spanish materials from various sources). The following July the captain called the settlers together and established the location of the town structure, now present day Main Plaza. The final act to establish the limits of the villa of San Fernando was the drawing of lots for the farm plots of the Islanders. Alamazán had selected the fertile area to the south of the villa between the river and the creek down to the confluence of the streams. Each family was consigned a plot sufficient to plant their crops; four single men were considered as two families. The banks of the two streams were deep enough in this area to make irrigation difficult, therefore, an acequia was envisioned directly from San Pedro Springs proceeding southward between the water courses to return to the river just prior to the confluence. This design presented two distinct advantages; first, it could service the Barrio del Norte, the presidio and the villa, as well as the Islander's fields; secondly, by following the high ground between the two water courses, it could irrigate lands on both sides, in contrast to the other acequias which only watered the lands toward the river. Just when the task was begun, and when it was completed was not recorded; but it is logical to assume that construction was initiated soon after assignment of the land. On January 11,1734 , by order of the viceroy, the lands were surveyed again and official title was granted to the Islanders. Excess land was also granted to eight other 
citizens of the villa ("Division of the Lands of the Canary Islanders in San Antonio", J. O. Leal, 1986, Bexar County Archives, San Antonio, Texas). In all probability, the acequia was in operation by this time.

On August 26, 1778, a petition was filed with Governor Ripperda stating: "Vicente Flores comes and says, that there being a vacant piece of land at the end of the 'Labor Alta' of Santa Maria which is bounded on the west with the acequia of San Pedro Springs; on the south with the lands of Don Francisco Xavier Rodriguez; on the east with the course of the acequia of the 'Labor Alta' which bears north by the hills of said San Pedro Springs" (Bexar County Courthouse, San Antonio, Spanish Archives 2:474).

This is roughly the area encompassed by San Pedro Springs on the north, San Pedro Avenue on the east, Evergreen Street on the south, and San Pedro Creek on the west. On June 26, 1784, a complaint was submitted to Governor Domingo Cabello by Don Francisco Arocha that Vincente Flores had failed to comply with the conditions of his grant, and therefore requested that the lands be transferred to him. The Governor investigated the matter, and upon finding that Flores had, indeed, failed to fence the property or care for it properly, awarded it to Arocha (City Council Minutes Volume C:194; Right-Of-Way Office [ROW] Files, NCB 996, Property Management Division, Main Plaza Building, San Antonio,). In June of 1830, Francisco Arocha's heir, José Nepomuceno Arocha, sold the southern portion to George Antonio Nixon, whose heirs subdivided the property into town lots (Bexar County Deed Records [BCDR] V1:174, Office of the County Clerk, Bexar County Courthouse, San Antonio). The northern portion was conveyed by Arocha to Alfred Shelby, who in turn, conveyed the property to Samuel A. Maverick on December 5, 1830 (BCDR C:194). After several court suits the property that is now designated as San Pedro Park was proven to be public lands, so granted by the King of Spain and therefore exempted from the property concerned.

The property to the south of Myrtle Street became the site of the Electric Park in 1906 . As the name indicated the use of an electrical scheme was a major feature to attract the public. The work on the park began in early January of 1906 with a planned opening of April 1. The grounds were extensively landscaped and featured a theater, restaurant, pavilion and natatorium. There were also outside amusements to thrill the guests. A "great jumping carousel, having four horses abreast" was installed at a cost of over \$25,000 (San Antonio Express [SAE] 5 January 1905. The manager, Mr. Sidney Weiss, boasted that "Electric Park when completed will not have a superior in the South" SAE, 5 January 1906). To insure this boast, The Greer-Sansom Construction Company of Pittsburgh, Pennsylvania, was contracted to provide a quarter-mile long "three-way figure eight" roller coaster, the largest of its kind in the United States (SAE, 18 January 1906). The San Pedro Acequia was incorporated into the landscape of the park.

A special section of the paper was produced in 1909 listing the many virtues of the city, a special point of pride was the San Antonio River. "In the early days the river furnished water for irrigating purposes and today traces are seen of the old ditches. One of the best known of these aqueducts is near the Frost Building in the center of the old section of the city" (SAE, 14 June 1909). The reference, of course, is to the remnants of the San Pedro Acequia, the last of the old ditches still flowing within the city limits. In December the venerable waterway was to be dealt the fate of the other acequias that had once watered the city. "The picturesque old North Flores Street ditch which irrigated the gardens of the earliest settlers from Spain and France who helped win San Antonio from sterility and the Indians must go" (SAE, 3 December 1909). The Board of Health noted that it no longer served its purpose and served only as a "menace to the public health" and ordered it closed (SAE, 3 December 1909). However, a large portion of the acequia still remained open north of the Five-point Intersection until 1912. At the first meeting of September, Alderman Fincham introduced a resolution providing for the closing and abandoning of the San Pedro ditch. "The measure was placed on its second and third reading and passed" (SAE, September 4, 1912). Thus the last existing acequia within the city was closed and forgotten. 


\section{METHODOLOGY AND CONCLUSIONS}

The excavations for the acequia were begun, on December 2, 1986, with the opening of a trench 185 feet south of, and parallel to, West Myrtle Street (Fig. 1). The location for this trench was selected based upon a projection of the last known position of the acequia that was exposed during excavation in 1985 (Cox 1986:5). The trench, eventually extended to $70 \mathrm{ft}$ in length, gave no indication of the acequia, and revealed only minor disturbances at several locations along its length, none of which were more than one and one-half feet beneath the gravel base below the surface of the parking lot. The backhoe was then repositioned to the immediate southwest corner of the station foreman's building and an attempt was made to open a second trench. Just below the parking lot paving a heavily stabilized base material was encountered. This consisted of a mixture of two cubic yards of yellow river gravel blended with one cubic yard of cement, which created a surface that proved too difficult to break through with the equipment provided. The operation was then relocated $50 \mathrm{ft}$ further south, where the same stabilized base was again encountered. Work was terminated for the day. Further archival materials were consulted which indicated that the true position was further to the west of the projected position that was first tested. On December third, a trench was opened $110 \mathrm{ft}$ south of West Myrtle Street, parallel to, but further west, than trench one. Almost immediately upon opening the unit a 4 in thick sidewalk was encountered at a depth of $13 \mathrm{in}$, with the acequia visible in the profile on the eastern edge of the unit. The unit was expanded over the acequia, the trench was profiled, photographs were taken, and a transit elevation procured. The acequia location indicated that the channel exited San Pedro Park 575 feet west of the intersection of West Myrtle and North Flores Streets. The profile revealed an unlined ditch $6.5 \mathrm{ft}$ wide, $3.5 \mathrm{ft}$ deep, with a concrete sidewalk covering the western portion. The top of the acequia was 18 in below the surface of the present parking lot (Fig. 2). The paved surface of the parking lot was recorded at 658.70 feet above sea level.

As a result of the investigation it was obvious that the depth of the acequia below the surface of the lot was sufficient to insure that the planned modification would not endanger the channel; however, further plans called for the relocation of an underground fuel storage tank near the location of the ditch further to the south. It was therefore recommended that the archaeologists be notified when such work was begun so that complete monitoring and documentation could be accomplished. When the plans for the location of the storage tank were presented to the Environmental Protection Agency (EPA), they were disapproved due to the proximity of the San Pedro Creek. After considerable delay, a compromise was reached which called for the location of the tank well beyond the area of the remains of the acequia. Therefore, no further monitoring was required.

Should future modification of the parking lot be considered, suitable archaeological investigations or monitoring should be considered. This portion of the San Pedro Acequia is considered eligible for nomination to the National Register of Historical Places. 


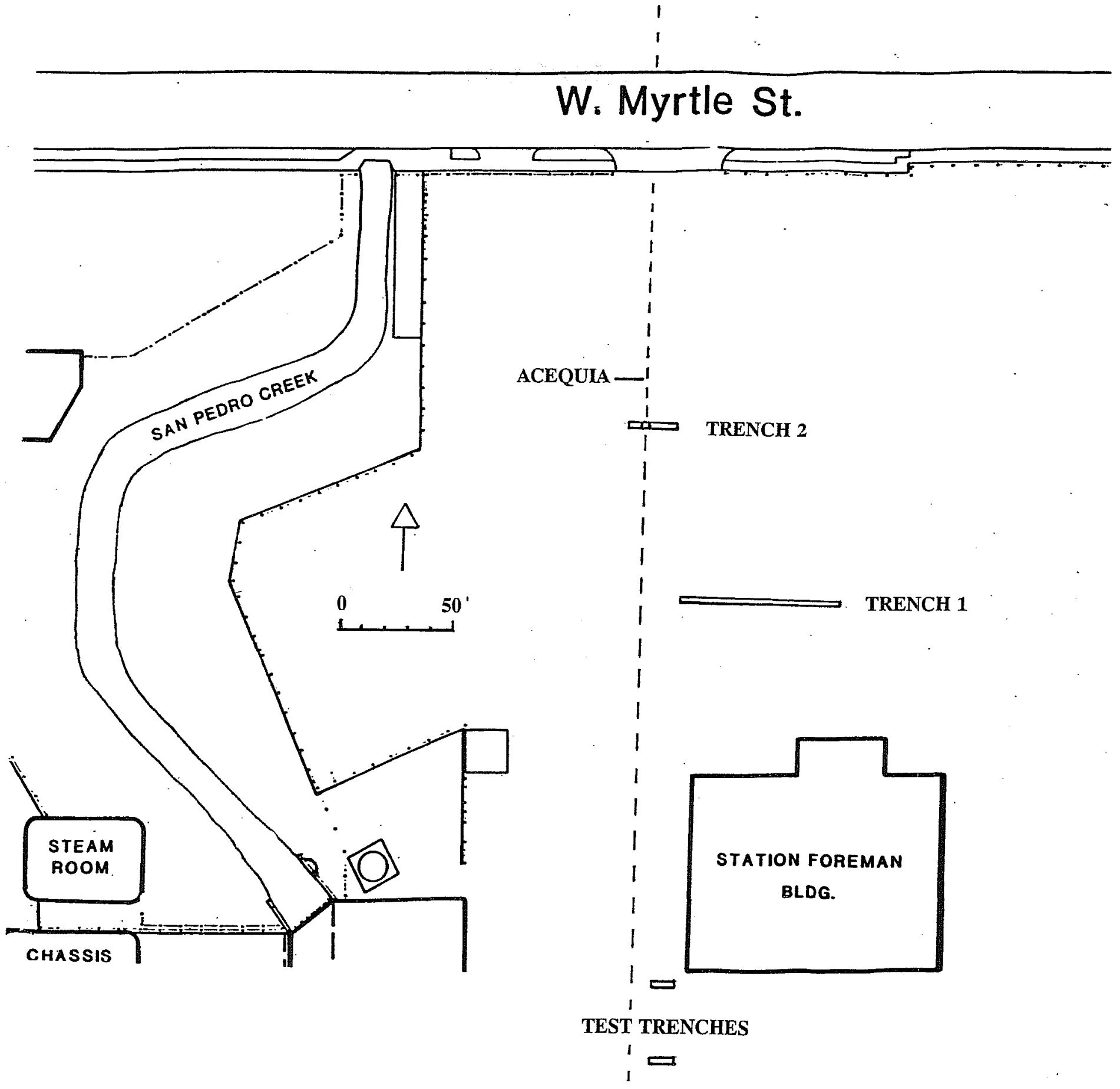

Figure 1. Locations of Excavated Trenches and San Pedro Acequia. 


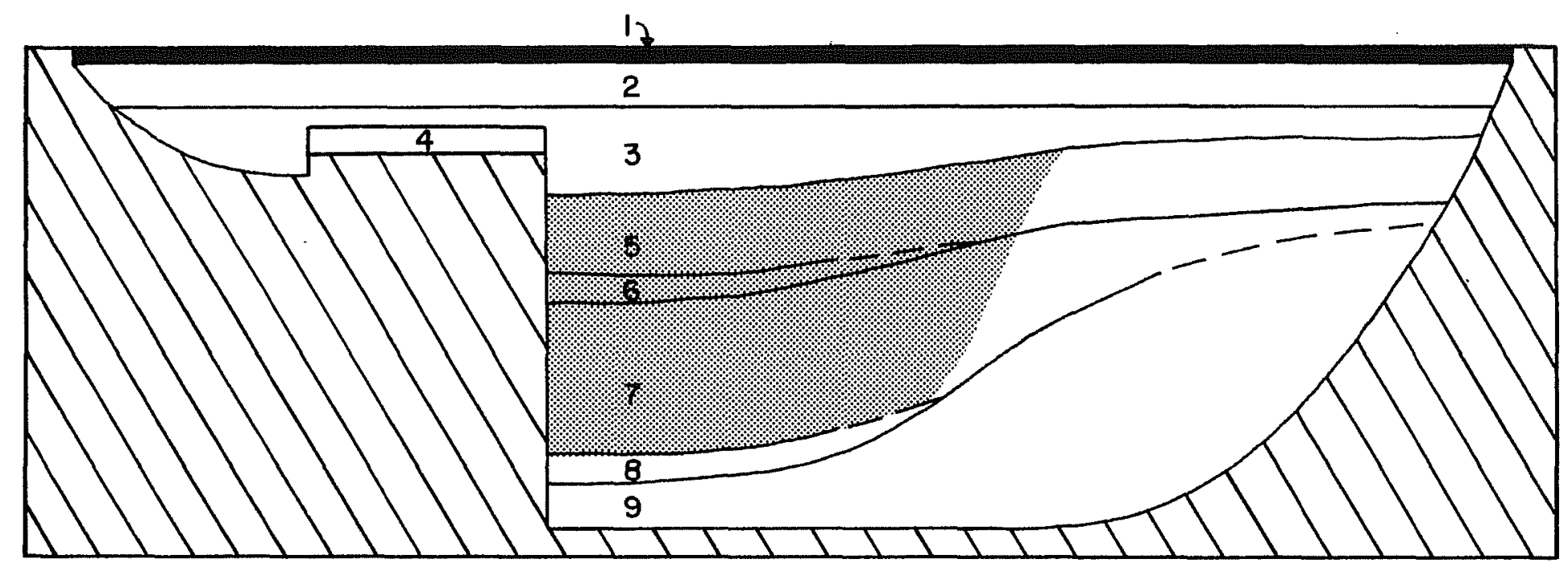
- Acequio fill
I-Asphalt
2 - Asphalt fill
3 - Brown silty soil, gravel
4 - Sidewalk
5 - Black clayey soil

$$
\begin{aligned}
& 6 \text { - Brown clayey soil } \\
& 7 \text { - Brown silty soil } \\
& 8 \text { - Gray clayey soil } \\
& 9 \text { - Gray clayey soil, gravel } \\
& \Delta \nabla \text { - Unexcavated }
\end{aligned}
$$

$$
\stackrel{0 \quad 1 \quad 2}{\text { feet }}
$$

NORTH WALL PROFILE ACEQUIA FEATURE 


\section{REFERENCES CITED}

Cox, I. W.

1986 Excavation of Portions of the San Pedro Acequia (41 BX 337) and A Search for the Arocha Acequia, San Antonio, Texas. Archaeological Survey Report No. 161. Center for Archaeological Research, The University of Texas at San Antonio.

Fox, A. A.

1978 Archaeological Investigations of Portions of the San Pedro and Alazan Acequias in San Antonio, Texas. Archaeological Survey Report No. 49. Center for Archaeological Research, The University of Texas at San Antonio.

Fox, A. A., I. W. Cox, L. Highley, and D. Hafernik

1989 Investigations at the Site of the New Bexar County Justice Center in Downtown San Antonio, Texas. Archaeological Survey Report No. 49. Center for Archaeological Research, The University of Texas at San Antonio.

Frkuska, A. J. Jr.

1981 Archaeological Investigations at the San Pedro Acequia, San Antonio, Texas. Archaeological Survey Report, No. 103. Center for Archaeological Research, The University of Texas at San Antonio.

San Antonio Express

1906 "New Electric Park", 5 January.

"At Work On Electric Park", 18 January.

1909 "The River Of The Old and New", 14 June.

"Picturesque North Flores Ditch Must Go", 3 December.

"Ditch to be Closed", 3 December.

1912 "City Provides For Third Relief In Police Force", 4 September. 
